\title{
TRIUKŠMO LYGIO IVERTINIMAS BENDROJO LAVINIMO MOKYKLOSE (BANDOMASIS TYRIMAS)
}

\author{
Vaida Batulevičienė, Melanija Tamulionytè, Aivaras Bajarūnas \\ Kauno kolegijos Medicinos fakultetas
}

Raktažodžiai: triukšmo lygis, mokiniai, mokyklos vidinè aplinka.

\begin{abstract}
Santrauka
Lietuvoje visuomeninès paskirties pastatų patalpose, kuriose vyksta mokymas ir (ar) ugdymas, triukšmo lygị valstybė reglamentuoja riboti iki $55 \mathrm{~dB}(\mathrm{~A})$. Klausos organo funkciją kenksmingai veikiantis triukšmo lygis nustatytas $75-85 \mathrm{dBA}$.

Šio tyrimo metu triukšmo lygio vertinimui buvo pasirinktos Kauno jèzuitų gimnazija ir Kèdainių rajono savivaldybès Krakių Mikalojaus Katkaus gimnazija. Atlikus tyrimą ir įvertinus triukšmo lygị dviejose skirtingose mokyklose, buvo nustatyta, kad triukšmo lygis abiejose gimnazijose pertraukų metu koridoriuose, foje ir valgyklose bei kūno kultūros pamokose viršija pagal HN33:2011 nustatytą maksimalų $\left(\mathrm{L}_{\max }\right)$ ir vidutinị $\left(\mathrm{L}_{\text {Aeq }}\right)$ triukšmo lygị visuomeninès paskirties pastatų patalpose, kuriose vyksta mokymas ir (ar) ugdymas. Didžiausias vidutinis triukšmo lygis $\left(\mathrm{L}_{\text {Aeq }}\right)$ buvo nustatytas Kauno jèzuitų gimnazijoje per kūno kultūros pamokas (83 dBA) yra kenksmingas. Visais atvejais Kauno jèzuitų gimnazijoje ịvertintas vidutinis triukšmo lygis $\left(\mathrm{L}_{\text {Aeq }}\right)$ viršijo 70 dBA. Krakių Mikalojaus Katkaus gimnazijoje pamokų (išskyrus kūno kultūros) metu vidutinis triukšmo lygis neviršijo leistino pagal HN33:2011 maksimalaus triukšmo lygio $\left(\mathrm{L}_{\max }\right)$, o vidutinị $\left(\mathrm{L}_{\text {Aeq }}\right)$ triukšmo lygi viršija tik $1,5 \mathrm{dBA}$. Kauno jèzuitų gimnazijoje statistiškai reikšmingai didesnis vidutinis triukšmo lygis $\left(\mathrm{L}_{\text {Aeq }}\right)$, nei Kèdainių rajono savivaldybės Krakių Mikalojaus Katkaus gimnazijoje. Tiketina, kad didesniam triukšmo lygiui Kauno jèzuitų gimnazijoje turi įtakos didesnis mokinių skaičius mokykloje ir klasėse, o pamokų metu dar ir skirtinga mokinių veikla.
\end{abstract}

\section{Ivadas}

Triukšmas šiuolaikinëje visuomenejje, vystantis tech- nologijoms, gausėjant transporto srautams, tampa svarbia aplinkos ekologine problema [1]. Triukšmą dažniausiai siee jame su intensyviu automobilių judejimu gatvèse ar ịvairiais prietaisais. Dažnai priprantame prie pastoviai veikiančio triukšmo ir jo nebejaučiame. $\mathrm{O}$ žmogaus balso ir nesuvokiame kaip triukšmo. Pasaulinès sveikatos organizacijos (PSO) duomenimis, Europoje 450 milijonų žmonių kasdien veikiami $55 \mathrm{dBA}$ triukšmo lygio, 113 milijonai veikiami 65 $\mathrm{dBA}$ triukšmo ir apie 10 milijonų patiria $75 \mathrm{dBA}$ triukšmą, o tai gali būti širdies ir kraujagyslių ligų priežastis [2].

Klausos pablogèjimo rizika atsiranda esant $75 \mathrm{dBA}$ triukšmui [2]. Daugelyje šalių nustatyta $85 \mathrm{dBA}$ triukšmo darbe saugumo riba. Pagal Lietuvos higienos normą HN33:2011 leidžiamojo triukšmo lygis pramogų, koncertų metu gali siekti $85 \mathrm{dBA}$, mokymosi erdvèse, kaip ir poilsio erdvèse - gyvenamosiose patalpose dirbant ịtemptą protini darbą - mažesnis kaip 55 dBA.

Triukšmo patologinis laipsnis priklauso nuo jo intensyvumo ir poveikio trukmès. Itin pavojingas triukšmas, veikiantis naktị besiilsintį žmogų. Žmonès, gyvenantys šalia intensyvios eismo gatvès, kurioje nakti sklinda 55 ir daugiau decibelų triukšmas, dažniau skundžiasi padidejjusiu kraujospūdžiu, padidejja miokardo infarkto, migrenos rizika, kraujyje padideja cholesterolio kiekis [3].

Klausos nuovargis išsivysto ilgesnị laiką (kelias valandas ar visą darbo pamainą) veikiant intensyviam triukšmui, kuris didesnis nei $85 \mathrm{~dB}$. Jei klausa perdirginama ir klausos nuovargis kartojasi kasdien, tai ilgainiui gali vystytis progresuojantis klausos susilpnejjimas, kuris dažniausiai baigiasi profesiniu neurosensorinès kilmès kurtumu [4, 5]. Nuolatinis triukšmas sukelia klausos nervinių ląstelių metabolinį išsekimą. Triukšmo pirmiausia yra veikiamos vidinès ausies sraigejje esančios sensoepitelinès ląstelès, suyra šių ląstelių segmentai, o vèliau degeneruoja klausos nervas dèl mielinio dangalo degeneracinių procesu [6, 7]. Triukšmo nespecifinis poveikis organizmui pasireiškia funkciniu centrinès ir vegetacinès nervu sistemos pakenkimu - veikiamos širdies ir kraujagyslių sistemos, kiek mažiau kvėpavimo sistema, sutrikdoma medžiagų apykaita 
[8], blogèja miego kokybè [9].

Vaikai dažniau nei suaugusieji susiduria su pernelyg dideliu triukšmu, triukšmo yra labiau veikiami, nei suaugusieji $[10,11]$. Mokykloje moksleiviai patiria didelị triukšmą [12 - 15]. Kadangi iš šios aplinkos norima maksimaliai gerų rezultatų, todèl savaime iškyla problema: ar triukšmas, kurị vaikas jaučia būdamas mokykloje, turi ịtakos jo savijautai bei mokymuisi?

Vokietijoje 5-10\% mokinių kenčia nuo lètinès klausos sutrikimų [12]. Vaikai, kurių gyvenamojoje aplinkoje triukšmo lygis yra daugiau nei $50 \mathrm{~dB}$ ir dažnai būna didesnis nei $60 \mathrm{~dB}$, jaučia stresą - padidèjęs sistolinis kraujospūdis, padidejęes širdies ritmo dažnis [16]. Daugeliui mokinių, veikiant dideliam triukšmui, sunku susikaupti, dirbti, taip pat sumažeja socialinis prisitaikymas, padidejja priešiškas elgesys, gali suprasteti pasiekimų rezultatai, palyginti su moksleiviais, kurie nebuvo veikiami padidejjusio triukšmo lygio $[13,14]$. Jungtinèse Amerikos Valstijose 12,5\% vaikams nuo 6 iki 19 metų amžiaus (maždaug 5,2 mln.) yra nustatyti vienos arba abiejų ausų triukšmo sukelti klausos slenksčio pokyčiai [17]. Kartais ryškaus triukšmo poveikio mokinių sveikatai galima nepastebėti, tačiau mokiniams, ypač jaunesnio amžiaus vaikams, sunkiau sukoncentruoti dèmesị atliekant klausymosi užduotis, suprastèja ilgalaikè atmintis, mokiniai dažniau būna susierzinę $[11,18,19]$. Triukšmo poveikis siejamas su vaikų hiperaktyvumu [19, 20]. Ilgai veikiama triukšmingos aplinkos vaikų klausa gali tiek susilpnèti, kad negali girdèti $16 \mathrm{~dB}$ aukšto ir žemo dažnio garsų. Jungtinėse Amerikos valstijose net 14 proc. mokyklinio amžiaus vaikų netenka klausos [17].

Tyrimo tikslas: ịvertinti triukšmo lygị bendrojo lavinio mo mokyklose.

\section{Tyrimo objektas ir metodai}

Triukšmo lygis buvo matuojamas Kauno jėzuitu gimnazijoje ir Krakių Mikalojaus Katkaus gimnazijoje. Kauno jèzuitų gimnazijoje mokosi 799 mokiniai, mokiniai mokosi nuo penktos klasės iki IV gimnazijos klasès, mokinių vidutinis kiekis klasėse 29, Kèdainių rajono savivaldybès Krakių Mikalojaus Katkaus gimnazijoje mokosi 310 mokinių, mokiniai mokosi nuo pirmos klasès iki IV gimnazinès klasès, vidutinis mokinių kiekis klasėse 21. Abiejose mokyklose pamokos vyksta viena pamaina - nuo 8 val iki 15 val. Krakių Mikalojaus Katkaus gimnazijoje pamokos ir pertraukos vyksta tradiciškai: pamokų trukmè - 45 min., visų pertraukų trukmė po 10 min., išskyrus pertrauką po trečios pamokos - 30 min. Kauno jèzuitų gimnazijoje pamokų trukmè tokia pati - 45 min., trumpujų pertraukų trukmé po $5 \mathrm{~min}$., o ilgosios pertraukos yra dvi po $55 \mathrm{~min}$. skirtingu laiku 5-8 klasių mokiniams ir gimnazinių klasių (I-IV) mo- kiniams. Jaunesniems mokiniams ilgoji pertrauka yra po trijų pamokų, o vyresniems - po ketvirtos pamokos. Toks pertraukų tvarkaraštis yra sudarytas siekiant sumažinti mokinių kiekị valgykloje. Taip pat mažesnis mokinių kiekis ir koridoriuose didžiają dalị ilgosios pertraukos.

Triukšmo lygis mokyklos patalpose buvo matuojamas garso lygio matuokliu - analizatoriumi „Delta OHM HD2110”. Matavimai vykdyti pagal LST ISO 1996-2:2008 standartą „Akustika. Aplinkos triukšmo aprašymas, matavimai ir įvertinimas. 2 dalis. Aplinkos triukšmo lygių nustatymas“. Triukšmo stiprumas arba intensyvumas matuojamas decibelais su koeficientu $A-d B(A) 30-110 d B$ intervale. Matuojami ir vertinami pagrindiniai triukšmo parametrai: vidutinis triukšmo lygis $\left(\mathrm{L}_{\text {Aeq }}\right)$, mažiausias tame laiko intervale pamatuotas triukšmo lygis $\left(\mathrm{L}_{\text {min }}\right)$ ir didžiausias tame laiko intervale pamatuotas triukšmo lygis $\left(\mathrm{L}_{\max }\right)$. Vidutie nis triukšmo lygis $\mathrm{L}_{\text {Aeq }}$ visuomet mažesnis už didžiausią triukšmo lygi $\mathrm{L}_{\max } \cdot$ Rezultatuose pateikiamas $\mathrm{L}_{\text {Aeq }}$. Mokyklų patalpose buvo pasirinktos vietos, kur mokiniai pertraukų metu praleidžia daugiau laiko: koridoriuose, foje, valgyklose. Triukšmo lygis buvo matuojamas ilgujjų ir trumpujų pertraukų metu. Taip pat triukšmo lygis buvo matuojamas kai kurių pamokų metu. Buvo pasirinkta kūno kultūros pamoka, kurios metu triukšmo lygis, tikètina, yra didžiausias lyginant su triukšmo lygiu kitų pamokų metu. Triukšmo lygio matavimui atsitiktinai pasirinktos dar kelios pamokos: biologijos, matematikos, geografijos. Kad atspindètų visą pamokos triukšmo lygi, buvo matuojama po 5 min. 3 kartus atsitiktinai pasirinktu pamokos metu. Visose pasirinktose vietose triukšmo lygis buvo matuojamas mažiausiai 3 kartus skirtingomis savaitės dienomis.

Triukšmo lygis vertinamas pagal HN33:2011 „Triukšmo ribiniai dydžiai gyvenamuosiuose ir visuomeninès paskirties pastatuose bei jų aplinkoje“, kur visuomeninès paskirties pastatu patalpose, kuriose vyksta mokymas ir (ar) ugdymas, maksimalus garso slègio lygis $\mathrm{L}_{\max }$ arba didžiausias triukšmo lygis negali viršyti $55 \mathrm{dBA}$, o vidutinis triukšmo lygis negali viršyti $45 \mathrm{dBA}$.

Triukšmo lygio rezultatų skirtumai vertinami Stjudent‘o dviejų nepriklausomų imčių testu (Origin v. 6.1). Reikšmingumo lygmuo $\mathrm{P}<0,05$.

\section{Tyrimo rezultatai}

Pertraukų metu mokyklų koridoriuose šurmuliuoja didelis kiekis mokinių. Trumpujų pertraukų metu mokiniams užtenka laiko tik pereiti iš vienos klasès ị kitą, o ilgosios pertraukos metu mokiniai spejja nueiti ị valgyklą ir nusipirkti pavalgyti pietus. Išmatavus triukšmo lygị buvo nustatyta, kad abiejose mokyklose triukšmo lygis pertraukų metu koridoriuose viršija maksimalų leistiną triukšmo lygi 
( $\left.\mathrm{L}_{\max }\right) 55 \mathrm{dBA}(1 \mathrm{pav}$.$) .$

Kauno jèzuitu gimnazijoje ilgosios pertraukos metu koridoriuose vidutinis triukšmo lygis $\mathrm{L}_{\text {Aeq }}$ siekè $72,7 \pm$ 3,25 dBA, o trumposios pertraukos metu $\mathrm{L}_{\text {Aeq }}-79 \pm 1,15$ dBA. Krakių Mikalojaus Katkaus gimnazijoje ilgosios pertraukos metu vidutinis triukšmo lygis $\mathrm{L}_{\text {Aeq }}$ sieke $63,28 \pm$ 2,6 dBA, o trumposios $\mathrm{L}_{\text {Aeq }}-67,95 \pm 2,8 \mathrm{dBA}$. Vertinant triukšmo lygi dviejose mokyklose pastebèta, kad abiejų mokyklų koridoriuose patikimai didesnis triukšmo lygis yra trumpujų pertraukų metu, nei ilgujų. Taip pat nustatyta, kad triukšmo lygis pertraukų metu mokyklų koridoriuose patikimai didesnis Kauno jëzuitų gimnazijoje nei Krakių Mikalojaus Katkaus gimnazijoje.

Pertraukų metu mokiniai būriuojasi koridorių erdvèse, kur sudarytos sąlygos bendrauti, užsiimti lengva veikla, pavalgyti. Tokios vietos mokyklose būna valgyklos, kavinès, kur yra suolų, mikštasuolių, kėdžių, stalų. Nors kartais užtenka ir palangès atramos, kad ịspūdžiu dalijimuisi susibur-

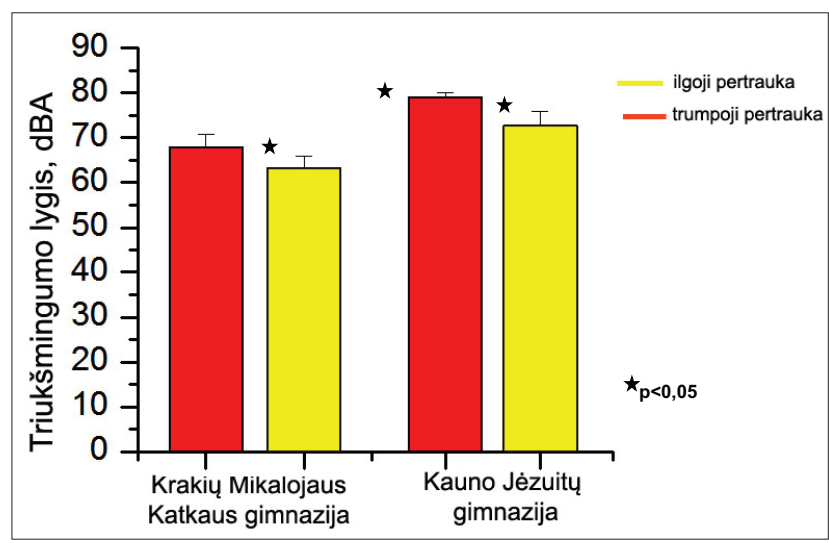

1 pav. Triukšmo lygis pertraukų metu mokyklų koridoriuose

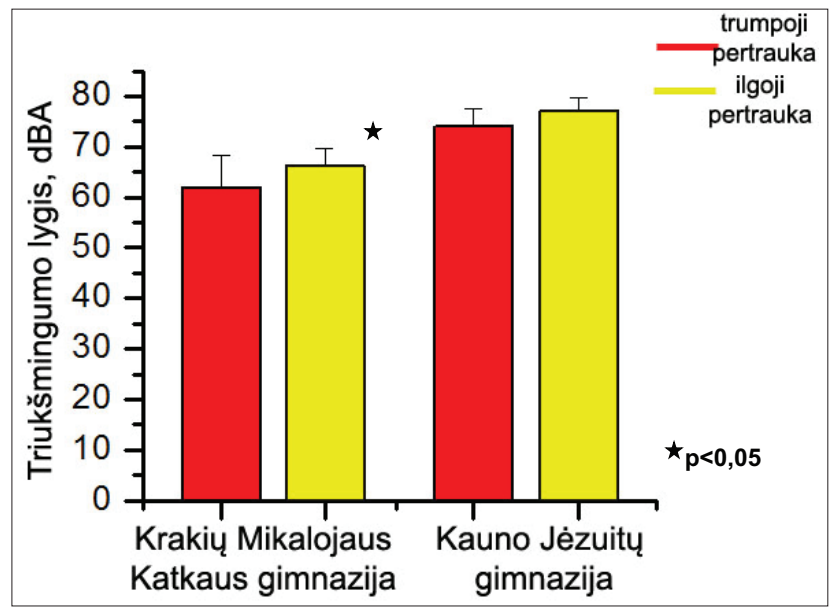

2 pav. Triukšmo lygis pertraukų metu mokyklų foje ir valgyklose tų grupelė moksleivių. Išmatavus triukšmo lygị buvo nustatyta, kad abiejose mokyklose triukšmo lygis pertraukų metu foje ir valgyklose viršija maksimalų leistiną triukšmo lygi $55 \mathrm{dBA}$ (2 pav.).

Kauno jėzuitu gimnazijoje ilgosios pertraukos metu foje ir valgyklose vidutinis triukšmo lygis $\mathrm{L}_{\text {Aeq }}$ sieké $77 \pm$ 2,65 dBA, o trumposios pertraukos metu $\mathrm{L}_{\text {Aeq }}-74 \pm 3,605$ dBA. Krakių Mikalojaus Katkaus gimnazijoje foje ir valgykloje ilgosios pertraukos metu vidutinis triukšmo lygis $\mathrm{L}_{\text {Aeq }}$ sieke $66,37 \pm 3,32 \mathrm{dBA}$, o trumposios $\mathrm{L}_{\text {Aeq }}-62,03$ $\pm 6,38 \mathrm{dBA}$. Vertinant triukšmo lygi dviejose mokyklose pastebèta, kad triukšmo lygis pertraukų metu mokyklų foje ir valgyklose patikimai didesnis Kauno jėzuitu gimnazijoje nei Krakių Mikalojaus Katkaus gimnazijoje.

Šiuolaikinè pedagogika skatina pamokų metu aktyvinti mokinių bendravimą, diskusijas. Tad visas 45 minutes klasejje pamokų metu nebūna tylu. $\mathrm{O}$ ir didžiają dali pamokos klasėje jaučiamas triukšmas. Kūno kultūros pamokose triukšmas kitoks dèl trypimo, kamuolio mušinèjimo ị grindis, o kartais ir šūkavimo. Tad kūno kultūros pamokų metu triukšmas vertinamas atskirai nuo kitų pamokų. Išmatavus triukšmo lygi kūno kultūros pamokose buvo nustatyta, kad abiejose mokyklose triukšmo lygis viršija maksimalų leistiną triukšmo lygị $55 \mathrm{dBA}$ (3 pav.). O kitų pamokų metu nustatyta, kad tik Kauno jėzuitų gimnazijoje triukšmo lygis viršija maksimalų leistiną triukšmo lygị $55 \mathrm{dBA}$ (3 pav.).

Kūno kultūros pamokų metu Kauno jèzuitų gimnazijoje triukšmo lygis $\mathrm{L}_{\text {Aeq }}$ siekè $83 \mathrm{dBA}$, o Krakių Mikalojaus Katkaus gimnazijoje $\mathrm{L}_{\text {Aeq }}-71,4 \mathrm{dBA}$. Biologijos, geograa fijos, matematikos pamokų metu Kauno jëzuitų gimnazijoje triukšmo lygis $\mathrm{L}_{\text {Aeq }}$ siekè $70,3 \pm 4,16 \mathrm{dBA}$, o Krakių Mikalojaus Katkaus gimnazijoje $\mathrm{L}_{\text {Aeq }}-46,5 \pm 6,05$ dBA. Nustatyta, kad triukšmo lygis pamokų metu patikimai didesnis Jėzuitų gimnazijoje nei Krakių Mikalojaus Katkaus gimnazijoje.

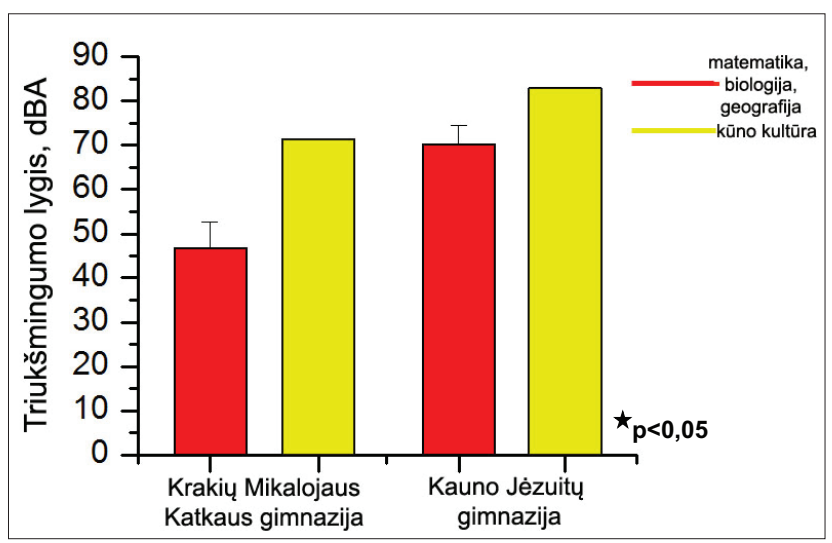

3 pav. Triukšmo lygis pamokų metu mokyklų klasėse 


\section{Rezultatų aptarimas}

Vertinant triukšmą mokyklose buvo nustatytas didžiausias triukšmo lygis kūno kultūros pamokų metu (3 pav.), kiek mažesnis triukšmas buvo trumpujų pertraukų metu. Vaikų plepèjimas paprastai siekia $\mathrm{L}_{\text {Aeq }}$ 61-65 dBA [21, 22]. Tačiau trypimas, spintelių durų varstymas ar kamuolio bumsẻjimas sukelia papildomą aplinkos triukšmą, prie kurio mokiniai taiko savo balso galimybes ir tokiu būdu pasiekiamas žymiai didesnis triukšmo lygis, nei tik kalbèjimas ramioje aplinkoje. Ilgujų pertraukų metu sumažèja mokinių judejjimas, mokiniai neskubèdami gali pietauti ar tiesiog ramiai šnekučiuotis. Nors Kauno jèzuitų gimnazijoje ilgosios pertraukos gerokai ilgesnès, nei Krakių Mikalojaus Katkaus gimnazijoje, mokiniai turètų nurimti ir, bent jau koridoriuose, triukšmo lygis turètų sumažèti, tačiau i Kauno jèzuitų gimnazijos ilgosios pertraukos sudèti ịeina 10 min. trumpujų pertraukų ir, vertinant $\mathrm{L}_{\text {Aeq }}$, triukšmo lygis vis tiek didesnis, nei Krakių Mikalojaus Katkaus gima nazijos triukšmo lygis ilgosios pertraukos metu (1 pav.). Tačiau Kauno jëzuitų gimnazijoje vertinant triukšmą trumpujų pertraukų metu triukšmo lygio standartinis nuokrypis mažesnis, nei ilgosios pertraukos triukšmo lygio standartinis nuokrypis, kas rodo ne tokị tolygų triukšmo lygi ilgujų pertraukų metu, kaip trumpujų pertraukų metu. Trumpujų pertraukų metu foje ir valgyklose triukšmo lygis buvo mažesnis nei ilgujų pertraukų metu (2 pav.). Šiose erdvėse mokiniai susiburia valgyti ar bendrauti, kai turi daugiau laiko. Kauno jèzuitų gimnazijoje per 5 trumposios pertraukos minutes mokiniai nespeja nei prisèsti, o tuo labiau, nusipirkti maisto kavineje ar valgykloje. Per trumpają pertrauką spejjama pereiti iš vieno kabineto ị kitą. Krakių Mikalojaus Katkaus gimnazijoje mokiniams nereikia taip skubèti, kaip Kauno jėzuitu gimnazijoje, kas gali turèti ịtakos kiek mažesniam triukšmo lygiui trumpujų pertraukų metu. Tad triukšmo lygis ilgujų pertraukų metu mokyklose patikimai mažesnis, ypač koridoriuose, nei trumpujų pertraukų metu, kai mokiniai priversti skubèti.

Pamokų metu mokiniai turètų susikoncentruoti ị dalyką. Pastaraisiais metais pamokos pasirenkamos labiau aktyvinančios mokinius, nei žinių perdavimas mokytojo aiškinimu ar skaitymu. Pamokos, kai vyksta diskusijos, argumentavimai, nuomonių apgynimai, vadinamos atviro tipo pamokomis. Nors mokyklose, kuriose vyksta atviro tipo pamokos, turi daug privalumų, tačiau didesnis triukšmo lygis buvo dažnai minimas kaip pagrindinis tokių pamokų trūkumas [15]. Pamokose triukšmo lygis priklauso nuo to, i kokią veiklą yra ịtraukiami mokiniai, todèl triukšmas individualiais atvejais gali skirtis. Priklausomai nuo mokiniu veiklos triukšmas pamokų metu gali skirtis net $30 \mathrm{dBA}[15$, $23,24]$. Matuojant triukšmą Kauno jëzuitų gimnazijoje ir
Krakių Mikalojaus Katkaus gimnazijoje standartinis nuokrypis, vertinant triukšmą mokykloje pamokų metu, buvo nustatytas didžiausias. Kauno jèzuitų gimnazijoje triukšmo lygis pamokų metu buvo nustatytas patikimai didesnis nei Krakių Mikalojaus Katkaus gimnazijoje. Skirtumas sieke daugiau nei 20 dBA. Krakių Mikalojaus Katkaus gimnazijoje nustatytas triukšmas $(46,5 \pm 6,05)$ yra labai artimas tokiam triukšmo lygiui, kai mokiniai pamokoje seddi tyliai $[15,23,24]$. Jei mokiniai įtraukiami ị tylią veiklą, triukšmas pamokos metu jau gali padidèti iki $56 \mathrm{dBA}$ [15]. Šiose ribose ir buvo nustatytas triukšmo lygis Krakių Mikalojaus Katkaus gimnazijoje. Kauno jėzuitų gimnazijoje triukšmo lygis svyravo nuo 69 iki 70,3 dBA. Toks triukšmo lygis atitinka mokinių aktyvumą, kai jie dirbdami gali tyliai šnekètis, o kai dirba darbo grupèse ir gali garsiai šnekètis, triukšmas pamokų metu gali siekti $77 \mathrm{dBA}$ [15]. Tačiau reikètų atkreipti dèmesị ị mokinių kiekị. Nors vidutiniškai Kauno jèzuitu gimnazijoje tik 8 mokinių skirtumas klasèje lyginant su Krakių Mikalojaus Katkaus gimnazijos klasėmis, tačiau mokinių kiekis klasėse, ypač ịtraukiant mokinius ị aktyvią veiklą, gali turèti įtakos bendram triukšmo lygiui mokyklose $[15,25]$. O jaunesnio amžiaus mokiniams taikyti aktyvios veiklos nè nerekomenduoja dèl šio amžiaus būdingo keliamo per didelio triukšmo [25]. Esant per dideliam triukšmo lygiui (didesnis nei $60 \mathrm{dBA}$ ) mokiniams gali būti sudètinga atlikti skaičiavimo, raštingumo, skaitymo užduotis, susikoncentruoti, silpnina ilgalaikę atmintį [15]. Vaikams, turintiems specialiujų ugdymosi poreikių, pavyzdžiui, klausos ar kalbos sutrikimų, dèmesio koncentravimo deficitą triukšmo lygis aplinkoje turètų būti 10 dBA mažesnis, nei specialių poreikių neturintiems vaikams [25].

Kai aplinkoje, koridoriuose pertraukų metu yra per didelis triukšmo lygis, mokiniai galètų naudoti klausos apsaugos priemones. Tačiau tyrimai parodè, kad tik mokinius skatinant, jie naudoja klausos apsaugą esant triukšmui mokykloje [26].

Triukšmą klasėje galima sumažinti triukšmo lygio 3-5 dBA ịrengiant akustiškai absorbuojančias lubas, tačiau triukšmas labiau sumažinamas (6-10 dBA) sumažinant mokinių skaičių klasèje [15].

\section{Išvados}

Atlikus tyrimą ir ịvertinus triukšmo lygị dviejose skirtingose mokyklose, buvo nustatyta, kad triukšmo lygis abiejose gimnazijose pertraukų metu koridoriuose, foje ir valgyklose bei kūno kultūros pamokose viršija pagal HN33:2011 nustatytą maksimalu $\left(\mathrm{L}_{\max }\right)$ ir vidutini $\left(\mathrm{L}_{\text {Aeq }}\right)$ triukšmo lygi visuomeninès paskirties pastatu patalpose, kuriose vyksta mokymas ir (ar) ugdymas. Didžiausias vidutinis triukšmo lygis $\left(\mathrm{L}_{\text {Aeq }}\right)$ buvo nustatytas Kauno jèzu- 
itų gimnazijoje per kūno kultūros pamokas (83 dBA) yra kenksmingas. Visais atvejais Kauno jèzuitu gimnazijoje įvertintas vidutinis triukšmo lygis $\left(\mathrm{L}_{\text {Aeq }}\right)$ viršijo $70 \mathrm{dBA}$. Krakių Mikalojaus Katkaus gimnazijoje pamokų (išskyrus kūno kultūros) metu vidutinis triukšmo lygis neviršijo leistino pagal HN33:2011 maksimalaus triukšmo lygio $\left(\mathrm{L}_{\max }\right)$, o vidutinị $\left(\mathrm{L}_{\text {Aeq }}\right)$ triukšmo lygi viršija tik 1,5 dBA. Kauno jèzuitu gimnazijoje statistiškai reikšmingai didesnis vidutinis triukšmo lygis $\left(\mathrm{L}_{\text {Aeq }}\right)$, nei Kẻdainių rajono savivaldybès Krakių Mikalojaus Katkaus gimnazijoje. Tikètina, kad didesniam triukšmo lygiui Kauno jèzuitų gimnazijoje turi įtakos didesnis mokinių skaičius mokykloje ir klasėse, o pamokų metu dar ir skirtinga mokinių veikla.

\section{Literatūra}

1. J. Ašmenskas A. Baubinas V. Obelenis, B. Šimkūnienè. Aplinkos medicina. Vilnius, 1997.

2. M. L. Munjal-Beepak Prasher (ed) Solid Mechanics and Its Applications. Book. Volume 102; IUTAM Symposium on Designing for Quietness, Proceedings of the IUTAM Symposium held in Bangalore, India, 2000.

3. Ramonas Z., Čikotinienė D. Žmonių sauga, Šiauliai, 2003.

4. Sulkowski WJ, Szymczak W, Kowalska S, Sward-Matyja M. Epidemiology of occupational noise-induced hearing loss (ONIHL) in Poland. Otolaryngol Pol 2004;58(1):233-236.

5. Sataloff RT, Sataloff J (Eds.) Occupational hearing loss. CRC Press 2006

6. Kirchner DB, Evenson E, Dobie RA, Rabinowitz P, Crawford J, Kopke R, Hudson TW. Occupational noise-induced hearing loss: ACOEM Task Force on occupational hearing loss. J Occup Environ Med. 2012;54(1):106-108.

http://dx.doi.org/10.1097/JOM.0b013e318242677d

7. Krishnamurti S. Sensorineural hearing loss associated with occupational noise exposure: effects of age-corrections. Int $\mathrm{J}$ Environ Res Public Health 2009;6(3):889-899.

http://dx.doi.org/10.3390/ijerph6030889

8. Recio A, Linares C, Banegas JR, Díaz J. Road traffic noise effects on cardiovascular, respiratory, and metabolic health: An integrative model of biological mechanisms. Environ Res 2016;146:359-370.

http://dx.doi.org/10.1016/j.envres.2015.12.036

9. Popp RF, Maier S, Rothe S, Zulley J, Crönlein T, Wetter TC, Rupprecht R, Hajak G. Impact of overnight traffic noise on sleep quality, sleepiness, and vigilant attention in longhaul truck drivers: Results of a pilot study. Noise Health 2015;17(79):387.

http://dx.doi.org/10.4103/1463-1741.169698

10. Folmer RL. Hearing-loss prevention practices should be taught in schools. In Seminars in Hearing Thieme Medical Publishers 2008; 29(01): 067-080.

http://dx.doi.org/10.1055/s-2007-1021774
11. Klatte M, Bergström K, Lachmann T. Does noise affect learning? A short review on noise effects on cognitive performance in children. Front Psychol 2013;4:578.

http://dx.doi.org/10.3389/fpsyg.2013.00578

12. Schick A, Klatte M, Meis M. Noise stress in classrooms. In contributions to psychological acoustics-results of the eight Oldenburg Symposium on psychological acoustics. Bibliotheks-und Informations system der Universität Oldenburg 2000.

13. Ristovska G, Gjorgjev D, Jordanova NP. Psychosocial effects of community noise: cross sectional study of school children in urban center of Skopje, Macedonia. Croatian medical journal 2004;45(4):473-476

14. Hétu R, Truchon-Gagnon C, Bilodeau SA. Problems of noise in school settings: A review of literature and the results of an exploratory study. Journal of Speech-Language Pathology and Audiology 1990.

15. Shield B, Greenland E, Dockrell J. Noise in open plan classrooms in primary schools: A review. Noise Health 2010;12(49):225.

http://dx.doi.org/10.4103/1463-1741.70501

16. Evans GW, Lercher P, Meis M, Ising H, Kofler WW. Community noise exposure and stress in children. J Acoust Soc Am 2001;109(3):1023-1027.

http://dx.doi.org/10.1121/1.1340642

17. Niskar AS, Kieszak SM, Holmes AE, Esteban E, Rubin C, Brody DJ. Estimated prevalence of noise-induced hearing threshold shifts among children 6 to 19 years of age: the Third National Health and Nutrition Examination Survey, 1988-1994, United States. Pediatrics 2001;108(1):40-43.

http://dx.doi.org/10.1542/peds.108.1.40

18. Schlittmeier SJ, Feil A, Liebl A, Hellbrück J. The impact of road traffic noise on cognitive performance in attention-based tasks depends on noise level even within moderate-level ranges. Noise Health 2015;17(76):148. http://dx.doi.org/10.4103/1463-1741.155845

19. Stansfeld S, Clark C. Health effects of noise exposure in children. Curr Environ Health Rep 2015;2(2):171-178. http://dx.doi.org/10.1007/s40572-015-0044-1

20. Forns J, Dadvand P, Foraster M, Alvarez-Pedrerol M, Rivas I, López-Vicente M, ... Grellier J. Traffic-related air pollution, noise at school, and behavioral problems in Barcelona schoolchildren: a cross-sectional study. Environ Health Perspect 2016;124(4):529.

21. Bottalico P, Graetzer S, Hunter EJ. Effects of voice style, noise level, and acoustic feedback on objective and subjective voice evaluations. J Acoust Soc Am 2015;138(6):EL498-EL503. http://dx.doi.org/10.1121/1.4936643

22. Mealings KT, Dillon H, Buchholz JM, Demuth K. An assessment of open plan and enclosed classroom listening environments for young children: Part 1-Children's Questionnaires. Journal of Educational, Pediatric \& (Re) Habilitative Audiology 2015 . 
23. Shield B, Dockrell JE. External and internal noise surveys of London primary schools. J Acoust Soc Am 2004;115(2):730738.

http://dx.doi.org/10.1121/1.1635837

24. Picard M, Bradley JS. Revisiting speech interference in classrooms: revisando la interferencia en el habla dentro del salón de clases. Audiology 2001;40(5):221-244. http://dx.doi.org/10.3109/00206090109073117

25. Mealings KT, Buchholz JM, Demuth K, Dillon H. Investigating the acoustics of a sample of open plan and enclosed Kindergarten classrooms in Australia. J Acoust Soc Am 2015;100:95-105. http://dx.doi.org/10.1016/j.apacoust.2015.07.009

26. Chermak GD, Curtis L, Seikel JA. The effectiveness of an interactive hearing conservation program for elementary school children. Language, Speech, and Hearing Services in Schools 1996;27(1):29-39.

http://dx.doi.org/10.1044/0161-1461.2701.29

\section{NOISE LEVEL IN GENERAL EDUCATION SCHOOLS (PILOT RESEARCH)}

\section{Batulevičienė, M. Tamulionytè, A. Bajarūnas}

Key words: noise level, students, school internal environment. Summary

Noise level in public buildings where training and (or) education takes place noise level is regulated by the state Lithuania to limit of $55 \mathrm{~dB}$ (A). Noise level of $75-85 \mathrm{dBA}$ can be harmful for hearing organ functioning.

In this study the noise level was evaluated in Kaunas Jesuit gymnasium and Kedainiai District Krakių Mikalojus Katkus gymnasium. It was found that the noise level in both high schools during breaks in the corridors, lobby and canteens and physical education classes exceeds the HN33:2011 the maximum $\left(\mathrm{L}_{\text {max }}\right)$ and average $\left(\mathrm{L}_{\text {Aeq }}\right)$ noise level of public buildings where training and (or) education is takes place. The highest average noise level $\left(\mathrm{L}_{\text {Aeq }}\right)$ was established during physical education classes ( $83 \mathrm{dBA})$ in Kaunas Jesuit gymnasium and it is harmful. In all cases estimated average noise level $\left(\mathrm{L}_{\text {Aeq }}\right)$ exceeds $70 \mathrm{dBA}$ in the Kaunas Jesuit gymnasium. The average noise level in Krakių Mikalojus Katkus gymnasium during classes (with the exception of physical education) did not exceed the alowdible maximum noise level $\left(\mathrm{L}_{\max }\right)$ and excess of only $1.5 \mathrm{dBA}$ the average $\left(\mathrm{L}_{\text {Aeq }}\right)$ noise level according to HN 33:2011. It was also found that the average noise level $\left(\mathrm{L}_{\text {Aeq }}\right)$ in Kaunas Jesuit gymnasium statistically significantly higher than Kedainiai District Krakių Mikalojus Katkus gymnasium. It is likely that higher noise level in Kaunas Jesuit High School causes more pupils both in the school and in the classroom, and the different student activities in classroom as well.

Correspondence to: vaida.batuleviciene@go.kauko.lt

Gauta 2016-09-30 